\title{
Teaching Computer Science with CLIL Methodology
}

\author{
Hrytsiuk O. S. \\ Kremenchuk Mykhailo Ostrohradskyi National University, Kremenchuk, Ukraine
}

Received: $01.10 .2020 \quad$ Accepted: 20.11 .2020

\begin{abstract}
In this paper, methodological and organizational aspects of applying CLIL methodology in teaching computer science for students of universities are analyzed. It is shown that European countries, as well as the United Kingdom, the United States of America, and Canada, where part of the curriculum has been taught in a foreign language for several decades, are most actively introducing content and language integration and promoting an interdisciplinary approach to education. CLIL methodology features and benefits are identified, namely, a comprehensive focus, stimulating learning environment, authenticity, active learning, gradual learning and collaboration. The peculiarity of CLIL methodology is that its use requires a stable elementary skill in the grammar of a foreign language, as well as knowledge of subject-specific language. In accordance with various conditions, CLIL model can be presented in various forms: it can be a full course of a foreign language discipline, a module from a specific topic area, a part of any course, a project, a laboratory workshop, and a research, too. The paper presents a plan for computer science lectures and labs in a foreign language, which contains seven stages, each of which is performed in English. Integration of computer science and teaching in English at the Kremenchuk Mykhailo Ostrohradskyi National University is implemented using developed bilingual course program "Computer for beginners". The course content includes a study of the material necessary for obtaining skills in using modern ICT and a personal computer using English glossary. Conclusions are drawn regarding conditions and principles of teaching computer science in a foreign language. The scientific novelty of the work is that for the first time a comprehensive analysis of the expediency of using CLIL methodology was carried out at the Kremenchuk Mykhailo Ostrohradskyi National University. The practical significance of the work is that its results can be used for further implementation of content and language integration in Ukraine universities. The development of new content and language integrated courses with CLIL methodology for teaching courses in a foreign language is considered promising.
\end{abstract}

Key words: content and language integrated learning, CLIL methodology, content-based approach, interdisciplinary approach, teaching computer science, subject-specific language, graduate education.

\section{Застосування методики CLIL у викладанні інформатики Грицюк О. С.}

\author{
Кременчуцький національний університет імені Михайла Остроградського, Кременчук, Україна
}

\begin{abstract}
Анотація. У статті проаналізовано методологічні й організаційні аспекти застосування CLIL методики у викладанні інформатики для студентів закладів вищої освіти. Показано, що найактивніше запроваджують предметно-мовну інтеграцію i просувають міждисциплінарний підхід в освітньому напрямку країни Європейського Союзу, а також Велика Британія, Сполучені Штати Америки, Канада, де частина дисциплін навчальної програми викладається іноземною мовою уже кілька десятиліть. Визначено особливості й переваги CLIL методики, а саме - комплексна спрямованість, стимулююче середовище навчання, автентичність, активне навчання, поступовість навчання і співпраця. Особливістю CLIL методики $€$ те, що для її використання необхідний стійкий елементарний навик володіння граматикою іноземної мови, а також знання спеціалізованої лексики. Відповідно до різних умов модель CLIL може бути представлена в різних формах: це може бути повний курс навчальної дисципліни іноземною мовою, модуль з певної тематичної області, частина будь-якого курсу, проект, лабораторний практикум, дослідження та інше. У статті репрезентовано план заняття з інформатики іноземною мовою, який містить сім етапів, кожен з яких виконується англійською мовою. Інтеграція викладання інформатики та англійської мови у Кременчуцькому національному університеті
\end{abstract}

\footnotetext{
Corresponding Author: Hrytsiuk Olena Serhiivna. +38(05366)30050. E-mail: hrytsiuk.elena@gmail.com. Kremenchuk Mykhailo Ostrohradskyi National University, Pershotravneva st, 20, Kremenchuk, Ukraine, 39600.

Відповідальний автор: Грицюк Олена Сергіївна. +38(05366)30050. E-mail: hrytsiuk.elena@gmail.com. Кременчуцький національний університет імені Михайла Остроградського, вул. Першотравнева, 20, м. Кременчук, Україна, 39600.
} 
імені Михайла Остроградського реалізується за допомогою розробленої двомовної програми курсу “Computer for beginners". Зміст курсу містить вивчення матеріалу, необхідного для отримання навичок користування сучасних IKT та персонального комп'ютера з використанням англійської лексики (термінів). Зроблено висновки щодо умов та принципів викладання інформатики іноземною мовою. Наукова новизна роботи полягає в тому, що вперше проведений комплексний аналіз досвіду застосування методики CLIL у Кременчуцькому національному університеті імені Михайла Остроградського. Практичне значення роботи зумовлене тим, що їі результати можуть бути використані для подальшого запровадження предметно-мовної інтеграції у закладах вищої освіти України. Перспективним вважається розробка нових інтегрованих предметно-мовних курсів із застосуванням CLIL методики для викладання дисциплін іноземною мовою.

Ключові слова: предметно-мовне інтегроване навчання, методологія CLIL, контентно-орієнтований підхід, міждисциплінарний підхід, викладання інформатики, предметна термінологія, вища освіта.

\title{
Использование методики CLIL в преподавании информатики
}

\author{
Грицюк Е. C.
}

Кременчугский национальный университет имени Михаила Остроградского, Кременчуг, Украина

\begin{abstract}
Аннотация. В статье проанализированы методологические и организационные аспекты применения методики CLIL в преподавании информатики для студентов высших учебных заведений. Показано, что активнее всего вводят предметно-языковую интеграцию и продвигают междисциплинарный подход в образовательном направлении страны Европейского Союза, а также Великобритания, Соединенные Штаты Америки, Канада, в которых часть дисциплин учебной программы преподается на иностранном языке уже несколько десятилетий. Определены особенности и преимущества методики CLIL, а именно - комплексная направленность, стимулирующая среда обучения, аутентичность, активное обучение, постепенность обучения и сотрудничество. Особенностью методики CLIL является то, что для ее использования необходим устойчивый элементарный навык владения грамматикой иностранного языка, а также знание специализированной лексики. В зависимости от различных условий модель CLIL может быть представлена в различных формах: это может быть полный курс учебной дисциплины на иностранном языке, модуль знаний определенной тематической области, часть какого-либо курса, проект, лабораторный практикум, исследование и т.д. В статье приведен план иноязычного занятия по информатике, который содержит семь этапов, каждый из которых выполняется на английском языке. Интеграция преподавания инсорматики и английского языка в Кременчугском национальном университете имени Михаила Остроградского реализуется с помощью разработанной двуязычной программы курса «Компьютер для начинающих» ("Computer for beginners"). Содержание курса включает в себя изучение материала, необходимого для получения навыков использования современных ИКТ и персонального компьютера с включением английской лексики (терминов). Сделаны выводы относительно условий и принципов преподавания информатики на иностранном языке. Научная новизна работы заключается в том, что впервые проведен комплексный анализ опыта применения методики CLIL в Кременчугском национальном университете имени Михаила Остроградского. Практическое значение работы обусловлено тем, что ее результаты могут быть использованы для дальнейшего внедрения предметно-языковой интеграции в учреждениях высшего образования Украины. Перспективным направлением исследований является разработка новых интегрированных предметно-языковых курсов с применением методики CLIL для преподавания дисциплин на иностранном языке.
\end{abstract}

Ключевые слова: предметно-языковое интегрированное обучение, методология CLIL, контентноориентированный подход, междисциплинарный подход, преподавание информатики, предметная терминология, высшее образование.

\section{Introduction}

The interpenetration of ideas and methods of various sciences is a typological feature of our time. Integration is an integrated approach necessary to solve the environmental, economic and social problems of society. The changes taking place in public life require the development of new ways of Education, pedagogical technologies that deal with individual development of the individual and creative initiative. Society needs a creative person who can think and explore. In modern conditions, a person has to solve complex problems, study and determine various options for action, and counteract new challenges in life with problems. The emphasis is shifted to the education of a truly free person who is able to think independently, acquire and apply knowledge, effectively cooperate in groups that are diverse in composition and profile, and be open to new contacts and cultural connections. This requires a broad introduction into the educational process of alternative forms and methods of conducting educational activities, one of which is integrated learning. 
The idea of integrating non-linguistic disciplines and a foreign language is the basis of teaching technology, when a number of courses are taught in a foreign language. With this approach, a foreign language is both a means of communication and cognition, and learning in your native and foreign languages becomes a single process. This idea is widely used in the study of humanities, natural science and technical disciplines, in particular, in the teaching of Computer Science.

Modern pedagogical science is focused on the development of a theoretical concept for the development of a fundamentally new model of Education CLIL, which is one of the most relevant areas of modern higher education and combines professional knowledge, subject-language and general language competencies. This combination contains a complex of pedagogical, psychological and methodological problems. In order to achieve the expected positive result, it is necessary to consistently develop effective teaching methods, taking into account the peculiarities of integrating academic disciplines with a foreign language.

CLIL is the acronym for Content and Language Integrated Learning [1]. At the same time, the term CLIL was coined in 1994 by David Marsh in Finland to describe an approach to teaching then evolving in Europe that was partly based on examples from bilingual education programs in Canada and Britain [2].

CLIL can be described as an educational approach where curricular content is taught through the medium of a foreign language, typically to students participating in some form of mainstream education at the primary, secondary, or tertiary level [3].

Despite some difficulties in implementing CLIL technology, it allows you to solve a wide range of educational tasks. Studying computer science in a foreign language is an additional tool for achieving educational aims and has positive aspects simultaneously for the formation of students' information and language competencies.

Actual issues of pedagogical research in the field of using CLIL methodology in universities are covered in works of A. Akbarov, K. Gonen and H. Aydoğan [4], M. King [5], P. Mehisto, D. March and M. Frigols [6]; J.Brewster [7], A. Bruton [8], J. Hunter and U. Smit [9] reveal benefits of the methodology; ways of implementing content and language integration are investigated by S. Lucietto [10], O. Meyer [11], T. Ting [12]; works of V. Boix-Mansilla [13], J. Klein [14], Y. Lenoir and A. Hasni [15] is devoted to introduction of an interdisciplinary approach in the application of the CLIL methodology. Features of the organization the teaching computer science with CLIL methodology in different countries are considered by $\mathrm{F}$. Moller and T. Crick [16], X. San Isidro [17], S. Darn [18], problems of using CLIL are covered in the research of A. Broca [19], M. Vega i M. Moscoso [20].

CLIL has two goals, namely, learning an academic discipline through a foreign language, and a foreign language through a non - linguistic discipline. That is, in this methodology, language is considered not as an object of study, but as a tool for learning other disciplines. CLIL provides the development of abilities, rethinking the learning process, motivation to learn and the formation of communication competencies.

The relevance of the work is that interdisciplinary approach in the integrated process of learning a foreign language is an important trend in the development of the modern educational environment. The implementation of an integrative approach to foreign language training helps to identify the main relationships of educational material. An extremely relevant plane of integration in the higher education system is subjectlanguage integration, which is aimed at using a foreign language as a medium for the content of learning and content as a resource for learning the language.

Objective: to analyze the application of the CLIL methodology in computer science classes in a foreign language.

The implementation of the research goal involves solving a number of tasks:

- understand the world and Ukrainian experience of implementing the CLIL methodology, to determine its advantages;

- trace the ways of implementing subject-language integration;

- investigate and determine the conditions and principles of integration of Computer Science and a foreign language;

- based on the analysis of conditions, formulate conclusions and recommendations for further application of the CLIL methodology for teaching computer science. 


\section{Material and Methods}

A set of research methods was used to solve the tasks set and achieve the purpose:

theoretical methods: study and analysis of linguodidactic, scientific and methodological, psychological and pedagogical literature, and experimental research results; theoretical and empirical material synthesis; actual universities' curriculums analysis;

empirical methods: study and generalization of pedagogical experience; observation of educational activities; experimental learning;

diagnostic methods: observation, testing, performing exercises, tasks, analyzing the results of Computer Science and Foreign Language teachers' activities.

This integrated approach ensures a comprehensive analysis of the selected research field.

The scientific novelty of the work is that for the first time a comprehensive analysis of the application of the CLIL methodology was carried out at the Kremenchuk Mykhailo Ostrohradskyi National University.

The practical significance of the work is due to the fact that its results can be used for further implementation of subject-language integration in higher education institutions of Ukraine.

In Europe, some of curriculum courses have been taught in a foreign language for several decades. Research in the field of CLIL is conducted by a number of European organizations and educational institutions, such as UNICOM, EuroCLIC, TIE-CLIL, Content and language Integrated Project (CLIP), the University of Nottingham, the Norwich Institute for Language Development, etc. [5].

Features of implementing CLIL methodology in different countries depend on the selected model. So, three CLIL models are known: soft (language-led), hard (subject-led), partial immersion. The first model is aimed at the linguistic features of a special context, the second means that $50 \%$ of the curriculum of subjects in the specialty are studied in a foreign language, and the third occupies an intermediate position, and is used when some modules from specialties program are studied in a foreign language.

The use of CLIL methodology is most common in Western European countries (Belgium, France, Germany, etc.). In addition, above methodology is used in Spain, Estonia, Russia, Poland, Latvia, Italy, Finland, the Czech Republic and other countries of the world. The list of specialized internet resources is presented in Table 1.

Table 1. Specialized online resources for studying CLIL methodology (Source: S. Darn [18])

\begin{tabular}{|c|c|}
\hline State & CLIL Internet Resources \\
\hline United Kingdom & $\begin{array}{l}\text { https://www.nfer.ac.uk/shadomx/apps/fms/fmsdownload.cfm?file uuid=A9819C1B- } \\
\text { C29E-AD4D-03A8-58D5CCC7A219\&siteName=nfer }\end{array}$ \\
\hline Estonia & http://www.meis.ee/rus-uudised?news_id=514 \\
\hline Spain & http://www.ub.edu/filoan/addendumen.html \\
\hline Italy & http://www.ucetam.org/portada/JB_2015/Gisella.pdf \\
\hline Germany & http://www.icri.eu/14/editorial.html \\
\hline Hungary & https://prezi.com/exgrzxxrbihn/clil-in-hungary-2015/ \\
\hline Finland & $\begin{array}{l}\text { http://www.celelc.org/projects/Past Projects/TNP Lanquages/TNP1 resources/SP } \\
\text { 6NatRepFI.pdf }\end{array}$ \\
\hline France & $\begin{array}{l}\text { http://www.onestopenglish.com/clil/clil-teacher-magazine/yourperspectives/clil-in- } \\
\text { france-interview-with-suzanne-dijon/500418.article }\end{array}$ \\
\hline
\end{tabular}

Content and language integrated learning is popular in Canada and the United States. The effectiveness of the technique is confirmed by studies conducted by Second Language Acquisition [4].

Researchers P. Mehisto, D. March and M. Frigols identify key features of CLIL methodology, which include integrated orientation, stimulating learning environment, authenticity, active learning, gradual learning, and collaboration [6].

By complex orientation, we mean the ability to learn a language within non-linguistic disciplines and, conversely, to study the content of the course in foreign language classes. This approach is based on the principle of integrating several academic disciplines. 
Subject-language training allows you to work on cross-cultural topics and projects. Creating a stimulating learning environment involves using a system of different types of learning activities in the course of classes and, as a result, strengthening students ' confidence in the results of learning activities. In addition, it means attracting authentic materials and developing students ' language competence. Authenticity in this case boils down to the fact that students independently signal their language needs. Active learning consists of stimulating joint work. Gradual learning involves reviewing and restructuring the skills, interests, and experience available in the student's Arsenal into more practical formats that match different learning styles, with an emphasis on creativity and critical thinking. Collaboration involves planning classes together with teachers specializing in CLIL methodology and teachers of disciplines. It is important to note that using this technique requires a stable elementary skill in the grammar of a foreign language, as well as knowledge of specialized vocabulary (the level of foreign language proficiency of a teacher must usually be confirmed by an International Certificate B2 level).

In addition to perfect command of a foreign language, subject-language integrated training requires a new approach to conducting classes. Teachers need to organize their work creatively, pay great attention to individual work, and diversify the forms of presentation of the material.

In addition to an impeccable command of a foreign language, CLIL requires a completely new approach to conducting classes. Teachers need to organize their work creatively, focus on individual and creative activities of students, and diversify the forms of presentation of the material. This means that studying computer science will become much more interesting and effective for students if it takes place within the framework of an activity-based and communicative approach.

According to different conditions, CLIL model can be presented in various forms: it can be a full course of an academic discipline in a foreign language, a module from a specific thematic area, part of any course, a project, laboratory workshops, research, and so on. The list of CLIL implementation forms also includes such techniques as an integrated lecture, a comprehensive workshop, an interdisciplinary conference, a comprehensive elective, etc.

Each lecture or lab using content and language integrated learning technology includes four "C" necessarily. There are content that is formation and development of knowledge, skills and abilities in a certain course branch; communication that is use of a foreign language as a means of communication; cognition that is development of students' cognitive and mental abilities; culture that is awareness of one's own personality as part of universal culture [9].

Thus, CLIL can easily adapt to different educational contexts and systems. The use of an integrated approach to teaching computer science in a foreign language forms a logically constructed and conceptually based system in which the instrumental value of language turns into a powerful incentive to master of the course content acquisition.

\section{Results}

The question of how to make teaching computer science in a foreign language more effective has different answers. It is possible to change the approach to learning, for example, to apply the competenceactivity approach that currently dominates in education. You can modify the content of training, giving it a modern applied or communicative character. The main thing in this process is to choose such training methods and tools that contribute to the realization of the needs of mastering and using computer science and a foreign language as a means of communication in the information, educational and socio - cultural spheres.

At the Kremenchuk Mykhailo Ostrohradskyi National University, CLIL methodology is implemented by conducting computer science integrated lectures or labs in a foreign language for students 1-2 years of study.

Learning computer science in the "original language" (after all, it is well known that almost all ICT terminology is in English) contributes to expanding learning opportunities and helps to create a learning environment that is a kind of interactive platform filled with meaningful tasks, in the process of which the level of responsibility of the student for the effectiveness of his training increases, builds his own learning experience. In the process of integrated teaching of Computer Science, a foreign language ceases to be only a training course, but turns into a means of communication and obtaining the necessary information.

The structure of an integrated lesson consists of the following stages: organizational stage, stage of motivation and updating of knowledge, introduction to the topic with the formulation of lesson goals, stage of 
updating, stage of finding a solution and discovering new knowledge, stage of working out new knowledge, stage of reflection. The plan for one computer science lesson is shown in Table 2.

Table 2. Plan of computer science lecture in a foreign language (Source: Author)

\begin{tabular}{|c|c|c|c|c|}
\hline Stage name & Stage aim & Stage content & Stage result & $\begin{array}{l}\text { Correlation } \\
\text { with } \\
\text { integration } \\
\text { conditions }\end{array}$ \\
\hline $\begin{array}{l}\text { Organizational } \\
\text { structure }\end{array}$ & Setting up for training & $\begin{array}{l}\text { Congratulations } \\
\text { to both lecturers } \\
\text { in English }\end{array}$ & $\begin{array}{l}\text { Readiness for } \\
\text { educational } \\
\text { activities }\end{array}$ & \\
\hline $\begin{array}{l}\text { Motivation and } \\
\text { updating of knowledge }\end{array}$ & Forming interest & $\begin{array}{l}\text { Watch a movie in } \\
\text { English about the } \\
\text { development of } \\
\text { social networks }\end{array}$ & $\begin{array}{l}\text { Interesting } \\
\text { in ICT }\end{array}$ & $\begin{array}{l}\text { Development of } \\
\text { the cognitive } \\
\text { sphere }\end{array}$ \\
\hline $\begin{array}{l}\text { Introduction to the } \\
\text { topic with the } \\
\text { formulation } \\
\text { of the lecture purpose }\end{array}$ & $\begin{array}{l}\text { Awareness of a } \\
\text { purpose of the lecture }\end{array}$ & $\begin{array}{l}\text { Joint discussion } \\
\text { of the lecture } \\
\text { purpose }\end{array}$ & $\begin{array}{l}\text { Understanding } \\
\text { a purpose of the } \\
\text { lecture }\end{array}$ & $\begin{array}{l}\text { Developing } \\
\text { analysis skills }\end{array}$ \\
\hline $\begin{array}{l}\text { Updating your } \\
\text { knowledge }\end{array}$ & $\begin{array}{l}\text { Creating conditions for } \\
\text { students to } \\
\text { consciously enter } \\
\text { learning space }\end{array}$ & $\begin{array}{l}\text { Creating } \\
\text { a dictionary of } \\
\text { already known } \\
\text { ICT terms that } \\
\text { were found in the } \\
\text { film }\end{array}$ & $\begin{array}{l}\text { Updating } \\
\text { a Lexical } \\
\text { knowledge }\end{array}$ & $\begin{array}{l}\text { Implementing } \\
\text { problem-based } \\
\text { learning }\end{array}$ \\
\hline $\begin{array}{l}\text { Finding a solution and } \\
\text { discovering new } \\
\text { knowledge }\end{array}$ & $\begin{array}{l}\text { Organization of } \\
\text { communication } \\
\text { interaction }\end{array}$ & $\begin{array}{l}\text { Search for new } \\
\text { terms and } \\
\text { discuss their } \\
\text { meaning }\end{array}$ & $\begin{array}{l}\text { Creating a new } \\
\text { glossary }\end{array}$ & $\begin{array}{l}\text { Getting a new } \\
\text { subject and } \\
\text { a language } \\
\text { knowledge }\end{array}$ \\
\hline $\begin{array}{l}\text { Practicing new } \\
\text { knowledge }\end{array}$ & $\begin{array}{l}\text { Presentation of joint } \\
\text { work result }\end{array}$ & $\begin{array}{l}\text { Create your own } \\
\text { text, shoot it } \\
\text { using devices, } \\
\text { and post it } \\
\text { on a social } \\
\text { network }\end{array}$ & $\begin{array}{l}\text { Developing the } \\
\text { ability to generate } \\
\text { text and present it } \\
\text { in virtual space }\end{array}$ & $\begin{array}{l}\text { Productive } \\
\text { English } \\
\text { proficiency, } \\
\text { ICT skills }\end{array}$ \\
\hline Reflections & $\begin{array}{l}\text { Self-assessment of } \\
\text { activities }\end{array}$ & $\begin{array}{l}\text { Discussion } \\
\text { of performance }\end{array}$ & $\begin{array}{l}\text { Ability } \\
\text { to analyze and } \\
\text { criticize }\end{array}$ & $\begin{array}{l}\text { Developing } \\
\text { critical } \\
\text { thinking }\end{array}$ \\
\hline
\end{tabular}

Integration of Computer Science and English teaching at the Kremenchuk Mykhailo Ostrohradskyi National University is implemented using the developed bilingual curriculum "Computer for Beginners". The course content contains study of material necessary for obtaining skills in using modern ICTs and a personal computer using English glossary (terms).

The corresponding multimedia course, built on the basis of the program of the integrated course of Computer Science and English "Computer for Beginners", consolidates existing knowledge, relying on the basic concepts of Computer Science and competence in the field of Computer Science, expands the skills of competent use of ICT tools and communication in English, enriches English glossary using built-in module "English Terms Electronic Dictionary", forms orientation skills in the English-language interface of application and Office programs. 
As a result of observing the activities of teachers of computer science, foreign language and students' educational activities in the context of integrated classes, it can be concluded that teaching computer science in a foreign language allows:

- expand the range of methods that allow students to "get" knowledge independently, and not just provide reproductive assimilation of knowledge;

- develop information competence;

- teach the use of technology that ensures the overall development of the individual;

- adapt to life in the information society.

For effective application of the CLIL methodology during integrated computer science and foreign language classes, it's necessary:

- up-to-date and interesting informative authentic educational material;

- support of the learning process jointly by computer science and Foreign Language teachers; proficiency;

- active interaction of all participants in the educational process and productive foreign language

- introduction of the cultural component in the subject content.

Content of teaching computer science in a foreign language should be based on the following principles:

- concurrency. The study of language sections goes in parallel with the advanced passage of the material in computer science classes;

- unambiguity. Unambiguity is necessary when selecting language units, without which the "man machine" dialogue is impossible»;

- algorithmization. Formalized unambiguous operation of language material forms the basis of algorithmization - an important principle of programming and computerization of learning;

- functionality. The definition of the object of algorithmization is carried out taking into account the functional structure that forms this programming principle and contains internal actions, the operation of which provides a mechanism for constructing and implementing a speech act (operations of comparison, selection, construction by analogy);

- pragmatism. This principle provides for the selection of speech material taking into account the subject orientation.

The best prerequisites for learning a foreign language in computer science lectures or labs are created if you have experience in cross-cultural communication. Participation of students in conferences, competitions and projects, academic mobility programs, publications in foreign journals, active citizenship, advanced training in seminars and courses, meetings of foreign delegations and communication experience in English provide not only linguistic, but also scientific and cultural experience that can be used as an illustration of professional communication in the classroom.

In integrated lectures, it is necessary to focus training not on language aspects, but on developing skills and knowledge that are related to the content of the discipline "Computer Science and Computer Engineering".

Special attention should be paid to information visualization when using CLIL methodology. So, for example, to explain new material, as well as summarize the material studied, you should use a variety of infographics (diagrams, tables, line graphs, etc.), illustrations, and videos.

Successful implementation of CLIL in a graduate education system largely depends on an integrated interdisciplinary approach to the learning process, in which a balance between a foreign language and other courses will contribute to necessary competencies formation. Therefore, it is important for CLIL-lecturers to give priority to such educational activities that develop critical thinking and focus on task-based learning to improve their competence level.

\section{Discussion}

In modern foreign studies of recent years devoted to subject-language integration, the concept of "versatile competence" is put forward, which gives direction to the further development of CLIL methodology [7-9].

The authors [10-12] consider it necessary, firstly, to strengthen the emphasis on the formation and improvement of competencies in non-linguistic subject areas with the simultaneous development of bilingual skills of academic discourse and, secondly, to give special significance to the cultural component, which 
among the four components of CLIL (Cognition, Culture, Content, Communication) is considered as a kind of "filter" through which the other three pass and in which they interpret and merge.

R. Klaassen pays attention to benefits of the interdisciplinary approach on which CLIL methodology is based. According to scientist, "the extent to which different disciplinary sources become synthesised is often one measure of success for interdisciplinary approach, next to other metrics like the realisation of new innovative technology. Each discipline contributes a piece of the puzzle" [21].

According to J. Hunter and U. Smit, the CLIL method has a number of advantages that convincingly indicate the effectiveness of using this method in the process of teaching foreign languages. First, the ability to integrate such aspects as consciousness, culture and communication in the learning process through a double focus - on the content of the subject and in a foreign language. Secondly, the ability to effectively master a foreign language and at the same time develop the criticality and mobility of one's own thinking. Finally, sufficient flexibility helps teachers apply the above methodology in various contexts [9].

Agreeing with the researchers, we believe that the main advantage of the CLIL method is that it has no restrictions in improving language skills and knowledge. CLIL also provides students with ample opportunities to develop their cross-cultural knowledge.

In addition, students have the opportunity to better learn and understand the culture of the language being studied, which contributes to the formation of socio-cultural competence. Thanks to the use of the CLIL method, according to B. Klimova, the student passes through a fairly large amount of speech material, which ensures full immersion in the natural language environment [22]. It should also be noted that working on various topics in computer science allows you to learn specific terms, certain language constructions, which helps to enrich the student's vocabulary with professional and technical terminology and prepares him for further study and application of the acquired knowledge and skills.

Among the positive characteristics of the CLIL methodology are the researchers P. Mehisto, D. March and $\mathrm{M}$. Frigols distinguish a communicative approach, full immersion in the language environment, working with a large amount of language material, and expanding students ' vocabulary through subject terminology [6].

T. Ting also highlights the ability to activate thought processes, connecting the cognitive level of perception and processing of information, which involves not only understanding the latter, but also its analysis, comparison and conclusions. Processes are stimulated by "working and live" content, information is used "here and now", a quick response is required, the process of transcoding information turns into the process of its perception and working with it. All this intensifies the work of memory and thought processes, so that knowledge becomes stronger and more orderly [12].

However, J. Mcdougald highlights certain difficulties in implementing CLIL, and focuses "on 4 key issues that are seldom taken into consideration or even a topic of conversation among practitioners: (1) opposition to language teaching by subject teachers, (2) experimental CLIL programs, (3) SLA skills needed by subject content teachers, and (4) lack of CLIL teacher-training programs" [23].

So, we note that CLIL methodology makes it possible to strengthen learning computer science at the expense of a foreign language, without requiring additional hours in the curriculum.

\section{$V$ Conclusion}

CLIL or content and language integrated learning is a methodology of teaching a course using foreign language tools, main purpose of which is to study the subject and improve language skills.

This methodology is not new. It has long been practiced by various universities in European countries, for example, Finland, Hungary, the Baltic states (Lithuania, Estonia), as well as the United Kingdom, Canada, the United States and other countries.

Successful application of CLIL indicates high potential of this methodology. Most scientists consider that the use of CLIL has great prospects, but its implementation requires a certain revision of traditional concepts and views on educational process organization. The need for reforms in the field of teaching foreign language in connection with the globalization process contributes to the active introduction of CLIL methodology in educational systems of the most world countries.

One of the benefits of the methodology is that it has no restrictions in improving language skills and knowledge from the course. CLIL also provides students with the opportunity to develop their cross-cultural 
knowledge. The methodology helps to use other learning strategies, apply innovative teaching methods and technologies, and increases students' motivation to learn computer science and a foreign language at the same time. In addition to benefits already listed, CLIL provides an opportunity to enhance learning computer science at the expense of a foreign language, without requiring additional hours in the curriculum.

The content and language integrated learning model allows to combine skills from single fields into a hole system, which at once improves knowledge quality of information technologies and a foreign language proficiency.

A comprehensive analysis of the expediency of using CLIL methodology at the Kremenchuk Mykhailo Ostrohradskyi National University allows to conclude that teaching computer science in a foreign language in university is based on the developed model, built on the basis of an content and language integrated approach, and presented in the form of a system aimed at forming students' language competence. With this approach, English is used as a tool of teaching computer science and at the same time is an object of learning. The use of methodology of content and language integrated learning corresponds to competence and functional approaches in the forming professional information competencies and foreign language competencies.

Further introduction of CLIL methodology in universities and development of new content and language integrated courses are considered promising.

\section{References}

1. Zeidmane, A., Cernajeva, S. (2011). Interdisciplinary Approach in Engineering Education. International Journal of Engineering Pedagogy, 1(1), 36-41. DOI: https://doi.org/10.3991/ijep.v1i1.1604

2. Brown, H, Bradford, A. (2017). EMI, CLIL, \& CBI: Differing approaches and goals. JALT2016 - Transformation in Language Education (Winc Aichi, Nagoya, Japan, November 25-28, 2016), 328-334.

3. Dalton-Puffer, C. (2011). Content-and-Language Integrated Learning: From Practice to Principles? Annual Review of Applied Linguistics, 31, 182-204. DOI: https://doi.org/10.1017/S0267190511000092

4. Akbarov, A., Gonen, K., Aydoğan, H. (2018). Content and (English) language integrated learning (CLIL) applied to math lessons. Acta Didactica Napocensia, 11(2), 1-10. DOI: https://doi.org/10.24193/adn.11.2.1

5. King, M. (2018). Content and language integrated learning (CLIL). The TESOL Encyclopedia of English language teaching. Hoboken, NJ: Wiley Blackwell, 1-6. DOI: https://doi.org/10.1002/9781118784235.eelt0173

6. Mehisto, P., March, D., Frigols, M. (2008). Uncovering CLIL: Content and Language Integrated Learning in Bilingual and Multilingual education. Oxford: Macmillan Education, 239.

7. Brewster, J. Thinking Skills for CLIL. URL: http://www.onestopenglish.com/thinking-skills-forclil/501197.article (accessed 12.09.2020).

8. Bruton, A. (2011). Is CLIL So Beneficial, Or Just Selective? Re-evaluating Some of the Research. System, 39(4), 523-532. URL: http://dx.doi.org/10.1016/i.system.2011.08.002 (accessed 03.09.2020).

9. Huntter, J., Smit, U. (2014). CLIL: the bigger picture. A respond to: A. Bruton. 2013. CLIL: some reasons why ... and why not. System, 44(4), 160-167. URL: http://dx.doi.org/10.1016/i.system.2014.03.001 (accessed 12.09.2020).

10. Lucietto, S. (2008). A Model for Quality CLIL Provision. International CLIL Research Journal, 1(1), 83-92.

11. Meyer, O. (2010). Towards quality-CLIL: successful planning and teaching strategies. Pulso, 33, 11-29.

12. Ting, T. (2011). CLIL ... not only immersion but also more than the sum of its parts. ELT Journal, 65(3), 314-317. URL: http://x.doi.org/10.1093/elt/ccr026 (accessed 08.09.2020).

13. Boix-Mansilla, V. (2010). Learning to Synthesize: The Development of Interdisciplinary Understanding. In R. Frodeman, J. T. Klein, \& C. Mitcham (Eds.), The Oxford Handbook of Interdisciplinarity (pp. 288-306). Oxford: Oxford University Press.

14. Klein, J.T. (2002). Introduction: Interdisciplinarity Today: Why? What? and How? In J. T. Klein (Ed.), Interdisciplinarity Education in K-12 and College. A Foundation for K-16 Dialogue (pp. 1-17). New York, NY: College Board Publications.. URL: http://dx.doi.org/10.1053/mda.2001.25961 (accessed 07.09.2020).

15. Lenoir, Y., Hasni, A. (2016). Interdisciplinarity in Primary and Secondary School: Issues and Perspectives. Creative Education,. 7, 2433-2458. URL: http://dx.doi.org/10.4236/ce.2016.716233 (accessed 05.09.2020).

16. Moller, F., Crick, T. (2018). A university-based model for supporting computer science curriculum reform. Journal of Computers in Education, 5, 415-434. DOI: https://doi.org/10.1007/s40692-018-0117-x

17. San Isidro, X. (2018). Innovations and Challenges in CLIL Implementation in Europe. Theory Into Practice, 57(3), 185-195. DOl: https://doi.org/10.1080/00405841.2018.1484038

18. Darn, S. Content and Language Integrated Learning (CLIL): A European Overview. URL: https://files.eric.ed.gov/fulltext/ED490775.pdf (accessed 10.09.2020).

19. Broca, A. (2016). CLIL and non-CLIL: differences from the outset. ELT Journal, 70(3), 320-331.

20. Vega, M.V., Moscoso, M.L. (2019). Challenges in the Implementation of CLIL in Higher Education: From ESP to CLIL in the Tourism Classroom. Latin American Journal of Content and Language Integrated Learning, 12(1), 144-176. DOI: https://doi.org/10.5294/laclil.2019.12.1.7 
21. Klaassen, R.G. (2018). Interdisciplinary education: a case study. European Journal of Engineering Education, 43(6), 842-859. DOI: https://doi.org/10.1080/03043797.2018.1442417

22. Klimova, B. (2012). CLIL and the Teaching of Foreign Languages. Procedia - Social and Behavioral Sciences, 47, 572-576. URL: http://dx.doi.org/10.1016/.jsbspro.2012.06.698 (accessed 12.09.2020).

23. Mcdougald, J.S. (2016). CLIL approaches in education: Opportunities, challenges, or threats? Latin American Journal of Content and Language Integrated Learning, 9(2), 253-266. DOI: https://dx.doi.org/10.5294/laclil.2016.9.2.1

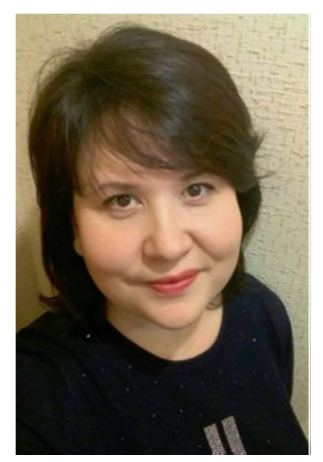

\section{Грицюк Олена Сергіївна,}

кандидат педагогічних наук, доцент, доцент кафедри інформатики і вищої математики,

Кременчуцький національний університет імені Михайла Остроградського,

адреса. вул. Першотравнева, 20, м. Кременчук, Україна, 39600

Тел. (05366) 3-00-50. E-mail: hrytsiuk.elena@gmail.com

\section{Hrytsiuk Olena Serhiivna,}

PhD (Ped.), Associated Professor, Associated Professor of Mathematics and Computer Science Department Kremenchuk Mykhailo Ostrohradskyi National University,

Pershotravneva st, 20, Kremenchuk, Ukraine, 39600

Tel. +38(05366) 30050. E-mail: hrytsiuk.elena@gmail.com

ORCID: 0000-0003-2117-626X

\section{Citation (APA):}

Hrytsiuk O. S. (2020). Teaching Computer Science with CLIL Methodology. Engineering and Educational Technologies, 8 (4), 64-73. doi: https://doi.org/10.30929/2307-9770.2020.08.04.06

\section{Цитування (ДСТУ 8302:2015):}

Грицюк О. С. Застосування методики CLIL у викладанні інформатики / Інженерні та освітні технології. 2020. Т. 8. № 4. С. 64 73. doi: https://doi.org/10.30929/2307-9770.2020.08.04.06

Обсяг статmі: сторінок-10 ; умовних друк. аркушів - 1,448. 